\title{
Art Music by Caribbean Composers: St. Vincent and the Grenadines
}

\section{Christine Gangelhoff \\ The College of The Bahamas ${ }^{1}$ \\ Cathleen LeGrand \\ Royal Thimphu College, Bhutan \\ INTRODUCTION}

St. Vincent was spotted by Columbus on the feast day of St. Vincent and named accordingly. The island was claimed by Spain but control was challenged by the British and the French. The native population, however, long resisted settlement by European colonizers from any country. Once French colonists arrived, they established plantations worked by slaves brought from West Africa. Control of the island changed hands during the various wars of the 18th century, remaining with the British, until the island was granted independence in 1979. St. Vincent is joined in its independence by the Grenadines, a chain of small islands stretching southward from St. Vincent towards Grenada. English is the official language of the nation, though a local French-based Creole is widely spoken (Kaufman, 2005).

St. Vincent is mountainous and volcanic. The damages wrought by periodic eruptions of the volcano, La Soufrière, have posed challenges to the political, agricultural and economic development of the island (Kaufman, 2005). Today, the major industries are tourism and banana production (Embassy, 2013).

A variety of festivals take place on St. Vincent and music is an essential component in these events. Among these festivals are Nine
Mornings (a pre-Christmas festival), Fisherman's Day (a week-long event ending on May 1), and Carnival, locally known as Vincy Mas. Most of the popular music styles common to other Caribbean nations are also widely heard in St. Vincent. Such styles include reggae, calypso, soca, steelpan and gospel (DeJong, 2005).

Traditional music includes string band, quadrille and bélé (Embassy, 2013). String bands and fife-and-drum bands are common on St. Vincent; quadrille and other ballroom music are often performed by such ensembles (Bilby \& Neely, 2009). Quadrille is particularly popular in north-eastern parts of St. Vincent, where a many residents are descended from the original Carib inhabitants of the island. The musicians and dancers who perform quadrille in this part of the island consider the musical form to be "one of the 'deepest' expressions of Carib identity" (Bilby \& Neely, 2009, p. 249). Elsewhere on St. Vincent, quadrille and other ballroom music are "viewed as local expressions of a broader Vincentian and African-Caribbean identity" and are often performed by "fife-anddrum ensembles known as 'boom drum' bands" (p. 249).

\footnotetext{
${ }^{1}$ Christine Gangelhoff, Assistant Professor, School of Communication and Creative Arts, The College of The Bahamas, P.O. Box N-4912, Nassau, Bahamas; Cathleen LeGrand, Librarian, Royal Thimphu College, Ngabiphu, Thimphu, Bhutan.

E-mail: cgangelhoff@cob.edu.bs

APA reference: Gangelhoff, C., \& LeGrand, C. (2013). Art music by Caribbean composers: St. Vincent and the Grenadines. The International Journal of Bahamian Studies, 19(2), 58-59.

https://jdoi.org/10.15362/ijbs.v19i2.191
}

(C) C. Gangelhoff \& C. LeGrand, 2013. Journal compilation (CThe International Journal of Bahamian Studies, 2013 


\section{REFERENCES}

Bilby, K., \& Neely, D. (2009). The Englishspeaking Caribbean: Re-embodying the colonial ballroom. In P. Manuel (Ed.), Creolizing contradance in the Caribbean (pp. 231-270). Philadelphia, PA: Temple University Press.

DeJong, N. (2005). St Vincent and the Grenadines. In Continuum encyclopedia of popular music of the world: Locations. Retrieved from http://www.credoreference. com/entry/contpmwl/st_vincent_and_the_gr enadines

\section{COMPOSERS}

Joel Bertram Miguel (1938- )

Patrick E. Prescod

\section{COMPOSITIONS, by composer}

\section{Miguel}

Saint Vincent land so beautiful (1967, adopted 1979, national anthem of Saint Vincent and the Grenadines)

\section{Prescod}

Let all the peoples praise you [Todos los pueblos canten] (with Victor Pilgrim, for choir)

Saint Vincent grammar school song (1966)

\section{SCORES}

\section{Miguel}

Saint Vincent land so beautiful. (n.d.). http://www.nationalanthems.info/vc .jpg

\section{Prescod}

Todos los pueblos canten. (n.d.). San Juan, Puerto Rico: Ediciones Schola Cantorum de Puerto Rico.
Embassy and Permanent Mission of St. Vincent and the Grenadines. (2013). SVG history and profile. Retrieved from http://www.embsvg.com/History_of_SVG.ht $\mathrm{m}$

Kaufman, W. (2005). Saint Vincent and the Grenadines.In Britain and the Americas: Culture, politics, and history. Retrieved from http://0-www.credoreference. com.helin.uri.edu/entry/abcbramrle/saint_vi ncent_and_the_grenadines

\section{RECORDINGS}

\section{Miguel}

National anthems of the world, vol. 7: Qatar Syria [CD]. (2006). Hong Kong: Marco Polo. Catalogue no. 8.225325 Track 17. Saint Vincent! Land so beautiful (0:57)

\section{SOUND FILES}

\section{Miguel}

Saint Vincent land so beautiful [MP3 file]. (2013). http://www.nationalanthems.info/vc.htm

\section{Prescod}

Saint Vincent grammar school song. (2013). http://upload.wikimedia.org/wikipedia/common s/9/9d/Saint_Vincent_Grammar_School_Song. ogg

\section{BOOKS AND ARTICLES}

Abrahams, R. D. (1972). Christmas and Carnival on Saint Vincent. Western Folklore, 31(4), 275289. doi: $10.2307 / 1498222$

King, B., \& Phills King, C. (eds.). (2012). Caribbean trailblazers: St. Vincent and the Grenadines, Vol. II. St. Vincent and the Grenadines: Kings SVG Publishers. ISBN: 09778981-9-9

[Volume II: biography of Patrick E. Prescod] 